\title{
The potential of mixing timber assets to financially offset negative effects of deer browsing on western redcedar
}

\author{
by Verena C. Griess ${ }^{1}$, Rajat Panwar ${ }^{1}$ and Julie Cool ${ }^{2}$
}

\begin{abstract}
Western redcedar (WRC) is a highly desirable species in British Columbia's Coastal Western Hemlock zone, both from a management and a conservation perspective. However, it is also highly palatable for ungulates. Existing countermeasures against browsing all have high costs and imperfect results in common. We used the portfolio method to display how diversification can help to lower investment risk. Using risk-return ratios of a WRC and Douglas-fir (DF), we derived species portfolios that yield maximum financial return per unit of risk. Financial indicators were calculated based on Monte Carlo simulations, which consider timber price fluctuation and browsing risk. Results show how economic risks of a forest investment could be reduced by creating a species portfolio. The optimum portfolio leading to most beneficial risk-return combination is $75 \% \mathrm{WRC}$ and $25 \% \mathrm{DF}$ if browsing is lowered using protective measures that double planting costs; and $30 \% \mathrm{WRC}$ and $70 \% \mathrm{DF}$ if no protective measures are applied. Accordingly, the most desirable risk-return combination is that of a mixed-species forest, whereas the 2 species don't have to be grown in intimate mixtures. Our research sketches a path forward that can help to ensure WRC will remain an important asset in BC's timber portfolio.
\end{abstract}

Keywords: western redcedar, Thuja plicata, Douglas-fir, Pseudotsuda menziesii, browsing damage, portfolio theory, forest management, cones, Monte Carlo simulation, deer browsing, decision support

\section{RÉSUMÉ}

Le thuya géant (TG) est une espèce très recherchée dans la zone côtière de la pruche de louest en Colombie-Britannique, tant d'un point de vue d'aménagement que de conservation. Cependant, elle est très appétissante pour les ongulés. Les mesures actuelles de protection contre le broutage sont toutes dispendieuses et les résultats sont souvent imparfaits. Nous avons utilisé la méthode du portefeuille afin de démontrer comment la diversification peut aider à réduire les risques liés à l'investissement. Au moyen des ratios de risques/rendement du TG et du sapin de Douglas (SD), nous avons dérivés des portefeuilles pour chaque espèce qui maximisait le rendement financier par unité de risque. Les indicateurs financiers ont été calculés selon des simulations de Monte Carlo qui tiennent compte de la fluctuation des prix du bois et le risque de broutage. Les résultats indiquent comment les risques économiques liés à un investissement forestier pourraient être réduits par la création d'un portefeuille pour chaque espèce. Le meilleur portefeuille menant à la meilleure combinaison entre le risque et l'investissement est constitué d'une portion de $75 \%$ de TG et de $25 \%$ de SD, dans le cas où le broutage est réduit au moyen de mesures de protection qui doublent les coûts de plantation, et d'une portion de $30 \%$ de TG et de $70 \%$ de SD si aucune mesure de protection nest envisagée. Par conséquent, la combinaison la plus souhaitable entre le risque et le rendement se retrouve dans les peuplements constitués d'un mélange d'espèces, où les deux espèces nont pas à se développer à proximité l'une de l'autre. Notre étude indique une direction à suivre qui pourrait assurer le maintien du TG en tant valeur importante du sein du portefeuille ligneux de la C.-B.

Mots clés : thuya géant, Thuja plicata, sapin de Douglas, Pseudotsuda menziesii, dégâts de broutage, théorie du portefeuille, aménagement forestier, cônes, simulation de Monte Carlo, broutage par le chevreuil, aide à la décision

\footnotetext{
${ }^{1}$ Department of Forest Resources Management, Faculty of Forestry, University of British Columbia. Vancouver, BC V6T 1Z4 *corresponding author's email: verena.griess@ubc.ca

${ }^{2}$ Department of Wood Science, Faculty of Forestry, University of British Columbia, Vancouver, BC V6T 1Z4
} 


\section{Introduction}

Western redcedar (Thuja plicata Donn ex D. Don), the third most commonly grown species in British Columbia (BC) after spruce and lodgepole pine (Brown 1999), has high significance from both economic and ecological standpoints. However, western redcedar (WRC) is under intensive browsing pressure by ungulates, leading to a stunted rate of growth and

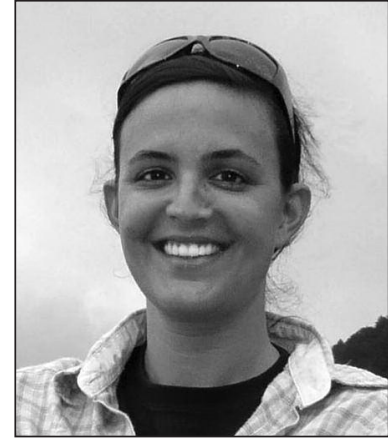

Verena C. Griess

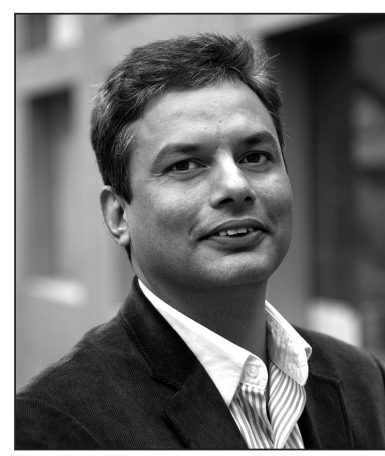

Rajat Panwar

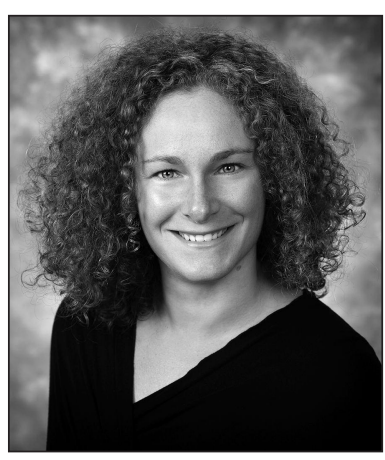

Julie Cool high mortality rates in young stands. With a decline in population of natural predators (e.g., Le Saout et al. 2014), the browsing problem has become even more severe. Especially in coastal BC, where planting WRC is considered risky, numerous countermeasures-such as the use of cones and fences-are being explored to reduce damage from browsing. Russel (2008) reported that an estimated $\$ 25$ million are annually spent on protective measures in the Pacific Northwest and coastal BC, yet those measures are falling short of alleviating this problem (Le Page and Banner 2005). Given the substantial implications of these losses, it is imperative that a solution is found that would allow us to fully harness WRC's economic and ecological potential. The present research aims to do so by identifying alternative forest management approaches that can be applied to offset financial risk related with growing WRC with and without the use of protective measures against browsing. One such alternative approach involves planting a mixture of species.

Even though numerous advantages regarding ecology, resilience, biodiversity and other aspects are associated with mixed species stands, $65 \%$ of the areas replanted in BC over the last decades are monocultures (B.C. Ministry of Forests, Mines and Lands 2010). In addition to being ecologically superior, mixed stands can significantly contribute to stabilizing return on investment. More specifically, mixing tree species lowers susceptibility to abiotic and biotic risks (Griess et al. 2012) and leads to the formation of a portfolio of assets by diversifying the product range coming from a forest enterprise (Knoke and Wurm 2006). If species used in a mixed forest investment portfolio have uncorrelated risks, a risk balancing effect can be expected. This effectively results in a more favorable financial risk-return combination, first described by Markowitz (1952) as the portfolio effect.

Douglas-fir (Pseudotsuga menziesii (Mirb.) Franco) is commonly found in natural mixtures with WRC (Montigny and Nigh 2007) and presents a logical choice to examine whether mixing Douglas-fir (DF) with WRC can produce a risk-reducing effect. In order to address this question, we propose the following two distinct yet complementary hypotheses:

$H_{0,1}$ : Mixing western redcedar and Douglas-fir in a timber portfolio has no economic benefit.

$H_{0,2}$ : Mixing western redcedar and Douglas-fir does not help to offset costs associated with damage caused by deer browsing.

Testing these two hypotheses will allow us to assess how the introduction of a second species lowers financial risks associated with growing a species that is prone to ungulate browsing.

\section{Material and Methods}

To answer our research question, we followed a methodology described by Neuner et al. (2013). As proposed above, we selected WRC and DF as our portfolio components. Additionally, we chose two management scenarios: the first assumes that cones are used as protective measures against browsing ("Cones" scenario); in the second, no cones are used ("High risk" scenario). We then simulated growth data for both species. We chose costs related to using cones rather than fences, as cones are most widely used and the extra cost for their use can be calculated on a tree-by-tree basis, allowing a straightforward inclusion into our model.

Log volumes available for sale in each modelling period were evaluated, as well as costs for logging using a feller buncher and grapple skidder, processing at roadside, and loading to a truck, based on species as well as average volume per stem. Expected cash flows were then transformed into annuities using a $3 \%$ discount rate.

Using Monte Carlo Simulation (MCS), we integrated risk of stand failure caused by natural disturbances and browsing as well as market risks caused by fluctuations in timber prices. A schematic representation of the process for a MCS run is provided in Fig. 1. Based on the output generated from MCS, we calculated species portfolios for both scenarios.

\section{Data preparation}

We used monthly log price data from the BC Ministry of Forests, Lands and Natural Resource Operations (Log Market Reports 2014) between January 2011 and June 2014. We assessed correlation coefficients of log prices for all combinations of the two species (Table 1) for which price data were available. Even though perfect correlations rarely occur in reality, diversification effects always occur when correlation is smaller than +1 . As can be noted, all combinations of the two species that price data were available for have correlation coefficients below +1 , which means that the desired portfolio effect will be achieved when mixing those species.

Out of the 10 species for which data were available, WRC and DF frequently grow together naturally and do not seem to display excessive interspecific competition (Montigny and Nigh 2007). While this would allow us to interpret a mixture of the two as a sum of two monospecific stands, this analysis treats both species as if grown in individual monospecific stands. In doing so, it is possible to apply straightforward assumptions regarding silvicultural costs as well as harvesting. 


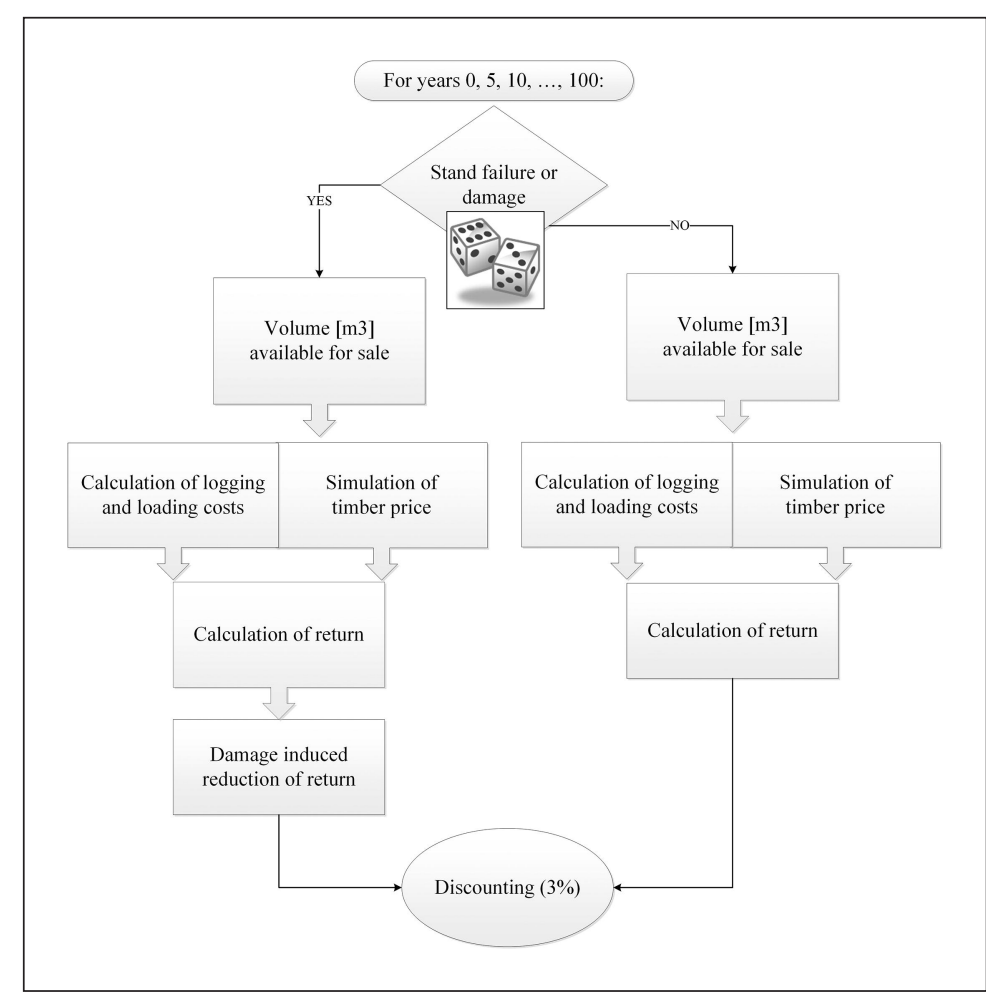

Fig. 1. Schematic flow chart of Monte Carlo simulations (simplified).

Given similar risks and considering only log price fluctuations, the correlation coefficient of WRC-DF is 0.17. Therefore a portfolio effect can be expected when these species are mixed in a forest company's or landowner's portfolio of assets. As ideal rotation times differ between both species, we chose annuity (Equation 1) as a financial indicator that would enable us to compare assets with varying investment times.

$$
a=R * i * \frac{(1+i)^{t}}{(1+i)^{t}-1}
$$

Where $R$ is the net present value of each asset, $i$ is the decimal interest rate and $t$ time.

In order to incorporate the effect of initial payments for countermeasures against deer browsing, we defined two scenarios. In the first scenario "Cones", we assumed that when a WRC stand was established, planting costs doubled due to the use of protective cones (or other physical seedling protection methods), while the costs for establishing the DF stands remained at a normal level. The associated failure rates for both species were equivalent, with 0.5 accumulated at age 100 (Fig. 2). As DF is grown in a 60-year rotation and WRC in a 100 -year rotation, WRC is exposed to a higher total risk than DF, leading to an overall more conservative assumption regarding its financial performance.

In the "High Risk" scenario, no investments are made in protective measures and costs for stand establishment for both species remain unchanged. However, the unprotected WRC seedlings had a much higher chance of being browsed and cumulative risk was increased by 0.25 until the seedlings reached a $1.5-\mathrm{m}$ height and were no longer vulnerable to browsing. The failure risk for DF stands remained unchanged ( 0.5 accumulated). The high risk scenario can be considered our baseline scenario. Yield data were modelled using the software TIPSY 4.3 (2013). Input variables are displayed in Table 2.

\section{Risk integration - Monte Carlo Simulation}

Monte-Carlo simulations (MCS) are commonly used to analyze the effects of stochastic processes by using random numbers to incorporate the dispersion of expected values into a model (Vose 2008). Thus, the method is very convenient to realistically simulate options in forest management (Griess and Knoke 2013). To integrate the effect of price correlation as well as the effect of risk on potential revenues, MCS were carried out for 42 stand types. First, a WRC and a DF monoculture were considered. We then carried out simulations for varying proportions of WRC - DF ranging between 95:5 and 5:95 (Table 3).

For each stand type, 2500 scenarios with randomly fluctuating net revenues for each harvest operation were simulated. Each of the 2500 scenarios comprised 20 periods of five years, leading to a total production time of 100 years in the case of WRC and 12 periods of five years, leading to a total production time of 60 years in the case of DF. The simulation was started at age 0 for all stands. During each simulation period (once every five years), failure due to damage caused by hazards or pests was possible. Failure was simulated using a binomial distribution indicating failure or no failure with associated probabilities (Table 2). If a stand failed, timber volume was read out. Based on those volumes, we calculated logging costs (Table 4) at fixed rates and timber value using randomly fluctuating prices based on the historic timber price data taking into account a 50\% damage-induced reduction of return. The stand was then reestablished at corresponding costs. All costs and revenues that occurred during one simulation run were discounted. As outlined earlier, ecological interdependencies between the two selected species are disregarded for this study. We assume the ratios of each species to be grown individually, rather than mixing both species more intimately.

Finally, we determined the optimum portfolio (OP). The OP is that combination of our assets with the highest Sharpe ratio (Sharpe 1994), a measure for risk-adjusted performance. The Sharpe ratio is calculated by subtracting the risk-free rate (e.g., the one achieved by investing in treasury bonds rather than stand establishment) from the rate of return for a portfolio and dividing it by the standard deviation of the portfolio returns. We assumed that in the "Cones" scenario, the costs for stand establishment of CAD $\$ 3200$ could alternatively be invested at no risk, whereas in the case of the "High risk" scenario an amount of CAD $\$ 1600$ was assumed to be invested at no risk.

\section{Results}

Fluctuating timber prices as well as potential stand failures due to browsing and other risks lead to a specific distribution of the calculated 2500 returns for each assessed stand type. A typical distribution based on MCS is displayed in Fig. 3. 
Table 1: Log price correlation coefficient of different species based on historical log market reports for the coastal region of BC between 01/2011 and 06/2014.

\begin{tabular}{|c|c|c|c|c|c|c|c|c|c|c|}
\hline & Alder & Birch & Cedar & $\begin{array}{l}\text { Cotton- } \\
\text { wood }\end{array}$ & Cypress & $\begin{array}{c}\text { Douglas- } \\
\text { fir }\end{array}$ & HemBal & Maple & Spruce & White Pine \\
\hline Alder & 1.00 & & & & & & & & & \\
\hline Birch & -0.28 & 1.00 & & & & & & & & \\
\hline Cedar & 0.43 & -0.57 & 1.00 & & & & & & & \\
\hline Cottonwood & 0.01 & 0.16 & -0.25 & 1.00 & & & & & & \\
\hline Cypress & -0.16 & 0.35 & -0.20 & 0.12 & 1.00 & & & & & \\
\hline Douglas-fir & -0.05 & -0.40 & 0.17 & 0.10 & -0.16 & 1.00 & & & & \\
\hline HemBal & -0.01 & -0.50 & 0.07 & -0.11 & -0.15 & 0.21 & 1.00 & & & \\
\hline Maple & 0.29 & 0.18 & -0.06 & 0.33 & -0.25 & -0.11 & 0.04 & 1.00 & & \\
\hline Spruce & -0.07 & -0.54 & 0.33 & -0.05 & -0.29 & 0.19 & 0.27 & -0.10 & 1.00 & \\
\hline White Pine & -0.04 & 0.13 & 0.16 & -0.05 & -0.10 & -0.11 & -0.03 & 0.15 & -0.20 & 1.00 \\
\hline
\end{tabular}

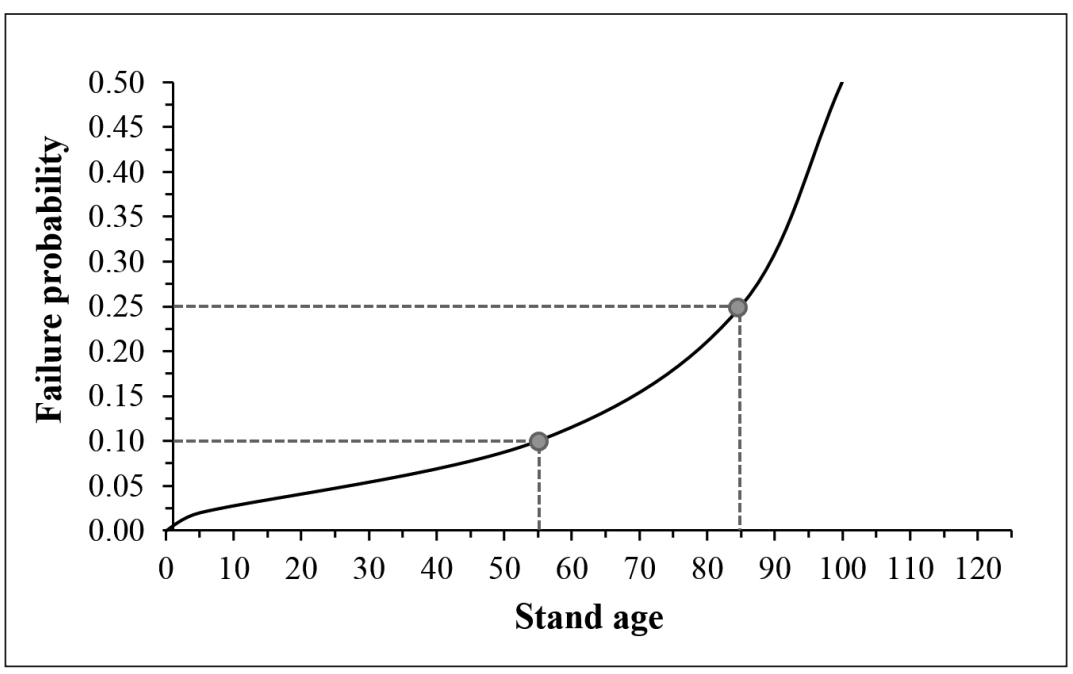

Fig. 2. To estimate failure probability in each 5 year period random numbers are drawn. For example, in period 51-55 years a random number between 1.00 and 0.00 is drawn. If the number is $\leq 0.10$ a hazard does occur. For the period 81-90 years the hazard increases and every random number between 1.00 and 0.00 that is $\leq 0.25$ a hazard does occur.

The frequency distributions of annuities for all 42 stand types show the differences in potential revenues that arose when considering risks. The frequencies ( $y$-axis) with which each annuity class ( $\mathrm{x}$-axis) was calculated summed up to 2500 for each stand type. The distribution of annuity displays the risk associated with each stand type. The left tails are particularly interesting, as a far-reaching left tail indicates high economic risk. In contrast, a short left tail represents a small economic risk. For each of the 42 distributions, an average annuity and standard deviation (STD) can be calculated. STD is commonly used to quantify financial risks in portfolio analysis. This risk-return combination for every combination of WRC and DF, as well as investments in only one of the two species, is then used to derive portfolios for each scenario.

Portfolios are displayed in Fig. 4. Associated financial indicators are shown in Table 5. When coming from an investment consisting only of WRC stands in both scenarios, the admixture of DF leads to a reduction in risk but also a reduction in return. While lower returns may seem undesirable at first, it is ultimately the combination of risk and return that counts. After all, the risk an investor bears can be inter-

\section{Discussion}

preted as a surcharge for the odds of earning higher revenues.

As a result, the optimum portfolio (OP) is made up of areal proportions of $75 \%$ WRC and 25\% DF in the "Cones" scenario and $30 \%$ WRC plus 70\% DF in the "High Risk" scenario, indicating that the most desirable risk-return combination is not that of a mono-species stand. Hence the risk premium that an investor would have to pay for any extra dollar in revenue is undesirably high at levels greater than that achievable with OPs on both graphs. When coming from a pure DF stand, any admixture of WRC leads to an increase in revenue while also reducing risks. When using protective measures, risk can be reduced from 27\% ("High Risk" scenario) to $16 \%$ ("Cones" scenario), while expected returns slightly decrease. The proportion of each investment (tree species) is given in areal proportion (hectares) and cannot be exchanged with financial proportions.

Our results show that, even when using a conservative approach regarding benefits, adding WRC to a DF investment may have a risk reduction as well as an expected overall higher return. In both scenarios, adding DF to the timber portfolio has a strong risk-reducing effect when coming from pure WRC stands. The same applies when adding DF to a pure WRC investment. Accordingly, we reject our first hypothesis "Mixing western redcedar with Douglas-fir in a timber portfolio has no economic benefit." Our second scenario displayed the situation if browsing risk was lowered by a higher initial investment during stand establishment. While the annuities of a mixed species portfolio were never higher than that of a mono-specific WRC stand, our results display how risk is further reduced when admixing DF. Accordingly, we cannot reject our second hypothesis "Mixing western redcedar with Douglas-fir does not help to offset costs associated with damage caused by deer browsing." However, when considering optimum risk-return combinations, a stand made up of $75 \%$ WRC and $25 \%$ DF emerges as the most rewarding choice. 
Table 2: Input information used for producing growth and yield tables based on TIPSY 4.3 as well as information on input data used for both scenarios within the Monte-CarloSimulation. a SI curves recommended by BC Ministry of FLNRO. b derived from log market report.

WRC

\begin{tabular}{|c|c|c|c|}
\hline TIPSY input & $\begin{array}{l}\text { Forest region } \\
\text { District } \\
\text { BGC zone } \\
\text { AVG slope } \\
\text { Site index } \\
\text { Rotation time [years] } \\
\text { Growth curve } \\
\text { OAF }\end{array}$ & \multicolumn{2}{|c|}{$\begin{array}{c}\text { Coast } \\
\text { Sunshine Coast } \\
\text { CWH } \\
10 \% \\
26\end{array}$} \\
\hline \multirow[t]{3}{*}{ MCS } & $\begin{array}{l}\text { Timber price }{ }^{\mathrm{b}}(S T D)[\mathrm{CAD} / \mathrm{m} 3] \\
\text { Correlation of prices } \\
\text { Interest rate }\end{array}$ & \multicolumn{2}{|c|}{$\begin{array}{l}0.17 \\
0.03\end{array}$} \\
\hline & $\begin{array}{l}\text { “Cones” Scenario } \\
\text { Establishment costs [CAD/ha] } \\
\text { Accumulated risk }\end{array}$ & $\begin{array}{c}3200 \\
0.5\end{array}$ & $\begin{array}{c}1600 \\
0.5\end{array}$ \\
\hline & $\begin{array}{l}\text { "High Risk" Scenario } \\
\text { Establishment costs [CAD/ha] } \\
\text { Accumulated risk }\end{array}$ & $\begin{array}{c}1600 \\
(+0.25 \text { in years } 0-15\end{array}$ & $\begin{array}{c}1600 \\
0.5\end{array}$ \\
\hline
\end{tabular}

$\mathrm{ac}=$ half-year age correction, $\mathrm{AVG}=$ average, $\mathrm{BC}=$ British Columbia, $\mathrm{BGC}=$ Biogeoclimatic zone, $\mathrm{CWH}=\mathrm{Coastal}$ Western Hemlock, DF = Douglas-fir, FLNRO = Forests, Lands and Natural Resource Operations, OAF = Operational Adjustment Factor, $\mathrm{SI}=$ site index, $\mathrm{STD}=$ standard deviation, $\mathrm{WRC}=$ western redcedar

${ }^{*}$ SI curves recommended by BC Ministry of FLNRO.

bderived from log market report.

Table 3: Analyzed stand types adding up to a total of 42 stands.

\begin{tabular}{lccccccccc}
\hline \multicolumn{3}{c}{ WRC } & Mixtures & \multicolumn{1}{c}{} & & DF \\
\hline Cones & 100 & $95: 5$ & $90: 10$ & $85: 15$ & $(\ldots)$ & $15: 85$ & $10: 90$ & $5: 95$ & 100 \\
High Risk & 100 & $95: 5$ & $90: 10$ & $85: 15$ & $(\ldots)$ & $15: 85$ & $10: 90$ & $5: 95$ & 100 \\
\hline
\end{tabular}

effect diminishing the benefits of mixing assets entirely, as such a scenario would either increase or decrease the overall differences between the species.

Another factor strongly influencing the overall results is the applied discount rate of 3\%. While the discount rate may appear comparably low, we would like to point out that the goal of our study is not to display real annuities that can be achieved by an actual forest operation, but rather the effects that considering financial attributes of various species may have. If higher discount rates are used, the negative effect of losses in early years as well as the negative effect of higher initial costs will have a disproportionally strong effect leading to a much larger ratio of DF in the portfolio. However, both the increased browsing risk as well as the price applied to simulate the use of cones are rough estimates and may greatly vary in reality. To fully understand what maximum financial investment ensuring an undisturbed growth of WRC would make sense, additional studies have to be carried out that ensure that the attributes used in the study are more than rough estimates. Once those attributes are known, a robust sensitivity analysis displaying future opportunities would be a seminal next step.

Finally, it would be highly valuable to better understand the consequences of planting the two species under consideration in more intimate mixtures rather than in separate stands. While we assume the

For a study like the one at hand, a number of assumptions have to be made. While the ability to make assumptions allows us to derive answers to a vast number of interesting and pressing questions, it has to be kept in mind that those answers suffer from a certain bias. Even though we tried to keep our assumptions as close to reality as possible, it is important to be aware of some potential frailties our approach may have. Examples include the fact that additional costs that in reality would arise, such as administrative expenses or costs for road building were not considered. Distance to mills as well as other specific attributes of the forest estate to be analysed play an important role. Generally it can be said that, due to the mathematical model formulation, when compared with an analysis where no logging and hauling costs were considered, overall optimum portfolios are only marginally influenced by additional cost. The calculated average annuities however, very much are. So when adding similar costs to both species, the curves will shift down on the y-axis. If the costs strongly differ between species they may even lead to an two species are planted separately for this study, planting them in more intimate mixtures will have numerous effects on the overall performance. Those effects include higher initial payments needed for stand establishment, possibly lower overall growth as well as technical challenges related to stand establishment and management. However, positive effects may include mitigation of overall risks, which has been displayed for other species combinations (e.g., Neuner et al. 2015), as well as a large number of ecologically beneficial effects. As such we recommend that more research be conducted before conclusively arriving at optimum proportions of mixed species for both "Cones" and High risk" scenarios. In that sense, our results should be treated as indicative which future studies can validate or refine, by further restricting the various assumptions and accordingly maneuvering study variables.

The cost assumed for manual protection of WRC seedlings used within this study is low. We assume one additional dollar for each planted seedling. In reality, these costs can be as high 
as $\$ 2.50-\$ 10.00$ (Henigman 1999). Gill (1999) even estimated costs of $>\$ 2500$ per hectare. Accordingly, planting costs are in reality likely to be much higher. The outcome of the portfolio analysis is strongly influenced by planting costs; accordingly, precise information on this matter is essential for reliable outcomes, specifically when discount rates increase as mentioned above. Additionally, measures of physical protection do not ensure a successful protection of planted trees. In this study, we have not considered potential losses regarding growth that may occur even when protective measures are taken which would lead to lower revenue from protected WRC trees. In

Table 4: Costs for logging using feller buncher and grapple skidder, as well as processing at roadside and loading to a truck. Costs were derived using the software tool FPInterface.

\begin{tabular}{|c|c|c|c|c|}
\hline \multirow[b]{2}{*}{ Age } & \multicolumn{2}{|c|}{ Western redcedar } & \multicolumn{2}{|c|}{ Douglas fir } \\
\hline & $\begin{array}{l}\text { Avg vol./ } \\
\text { stem [m3] }\end{array}$ & $\begin{array}{c}\text { costs/stem } \\
{[\text { CAD] }}\end{array}$ & $\begin{array}{l}\text { Avg vol./ } \\
\text { stem [m3] }\end{array}$ & $\begin{array}{c}\text { costs/stem } \\
{[\mathrm{CAD}]}\end{array}$ \\
\hline 0 & 0.000 & 0 & 0.000 & 0 \\
\hline 5 & 0.000 & 0 & 0.000 & 0 \\
\hline 10 & 0.001 & 242 & 0.001 & 244 \\
\hline 15 & 0.009 & 61 & 0.010 & 58 \\
\hline 20 & 0.042 & 30 & 0.038 & 31 \\
\hline 25 & 0.099 & 21 & 0.084 & 22 \\
\hline 30 & 0.164 & 18 & 0.132 & 19 \\
\hline 35 & 0.230 & 16 & 0.184 & 17 \\
\hline 40 & 0.308 & 15 & 0.231 & 16 \\
\hline 45 & 0.373 & 14 & 0.278 & 15 \\
\hline 50 & 0.437 & 13 & 0.328 & 14 \\
\hline 55 & 0.517 & 13 & 0.383 & 14 \\
\hline 60 & 0.600 & 12 & 0.439 & 13 \\
\hline 65 & 0.686 & 12 & - & - \\
\hline 70 & 0.769 & 12 & - & - \\
\hline 75 & 0.850 & 11 & - & - \\
\hline 80 & 0.947 & 11 & - & - \\
\hline 85 & 1.060 & 11 & - & - \\
\hline 90 & 1.172 & 11 & - & - \\
\hline 95 & 1.290 & 11 & - & - \\
\hline 100 & 1.407 & 10 & - & - \\
\hline
\end{tabular}

combination, both effects may reduce the ratio of WRC in the optimum portfolio. This also means that we may have underestimated any negative effects of an increased failure rate.

Regarding the timber price data used, the historical time span considered goes back only until January 2011. This means that bigger price drops that occurred in 2008 and following years are not captured by our price history. This may be interpreted in two ways: on the one hand, it may be a better reflection of the economic reality where price fluctuations are not often too drastic, yet on the other, disregarding those extremely volatile conditions may have made our study assumptions too positive, as there is some evidence to suggest that those extremes are germane to modern economies (Panwar et al. 2015) and therefore occur periodically. Also, we did not assume any increase in future log prices. But then again, while this may indicate a slight underestimation of prices, it points at a rather conservative calculation of financial indicators.

The method itself has been scientifically proven (e.g., Clasen et al. 2011). Still, it has to be made clear that our results display tendencies and are foremost to trigger an interest in the consideration of mixing species, where mono-cultures would have been the classical choice, as confirmed by the fact that $65 \%$ of the areas replanted in BC over the last decades are monocultures (B.C. Ministry of Forests, Mines and Lands 2010).

\section{Conclusions}

In addition to fulfilling demands regarding timber production and securing numerous additional requirements such as recreational services, habitat provision, carbon sequestration and others, forest management must be responsive to impending implications of a changing climate in the near future. To meet those challenges, forest managers must maintain a large variety of options within forests worldwide. Mixing species-either in large blocks or in more intimate mixtures-is an option that can help reaching those goals. Sustainable forest management cannot allow a species that has a strong potential to meet with the upcoming challenges, such as WRC, to be driven from areas where it grows the best. However, all efforts must also be financially viable, and finan-

Table 5: Financial indicators for investments comprised out of a single species only (western redcedar or Douglas-fir) as well as for the derived optimum portfolios.

\begin{tabular}{lcccccc}
\hline & \multicolumn{3}{c}{ Cones Portfolio } & & \multicolumn{2}{c}{ High Risk Portfolio } \\
\cline { 2 - 7 } Incl. logging costs & $\mathbf{1 0 0 \%}$ WRC & MPF 75:25 & $\mathbf{1 0 0 \%} \mathbf{D F}$ & $\mathbf{1 0 0 \%}$ WRC & MPF 30:70 & $\mathbf{1 0 0 \%}$ DF \\
\hline Average annuity & 212 & 204 & 179 & 265 & 206 & 181 \\
Risk (STD) & 39 & 33 & 60 & 2.15 & 55 & 3.31 \\
Sharpe Ratio & 4.78 & 5.47 & 2.60 & & 2.61
\end{tabular}

\begin{tabular}{lcccccc} 
& \multicolumn{3}{c}{ Cones Portfolio } & \multicolumn{3}{c}{ High Risk Portfolio } \\
\cline { 2 - 7 } No logging costs & $\mathbf{1 0 0 \%}$ WRC & MPF 70:30 & $\mathbf{1 0 0 \%}$ DF & $\mathbf{1 0 0 \%}$ WRC & MPF 30:70 & $\mathbf{1 0 0 \% ~ D F}$ \\
\hline Average annuity & 240 & 217 & 164 & 269 & 195 & 163 \\
Risk (STD) & 42 & 33 & 52 & 102 & 49 & 32 \\
Sharpe Ratio & 5.15 & 5.81 & 2.67 & 2.40 & 2.63 \\
\hline
\end{tabular}




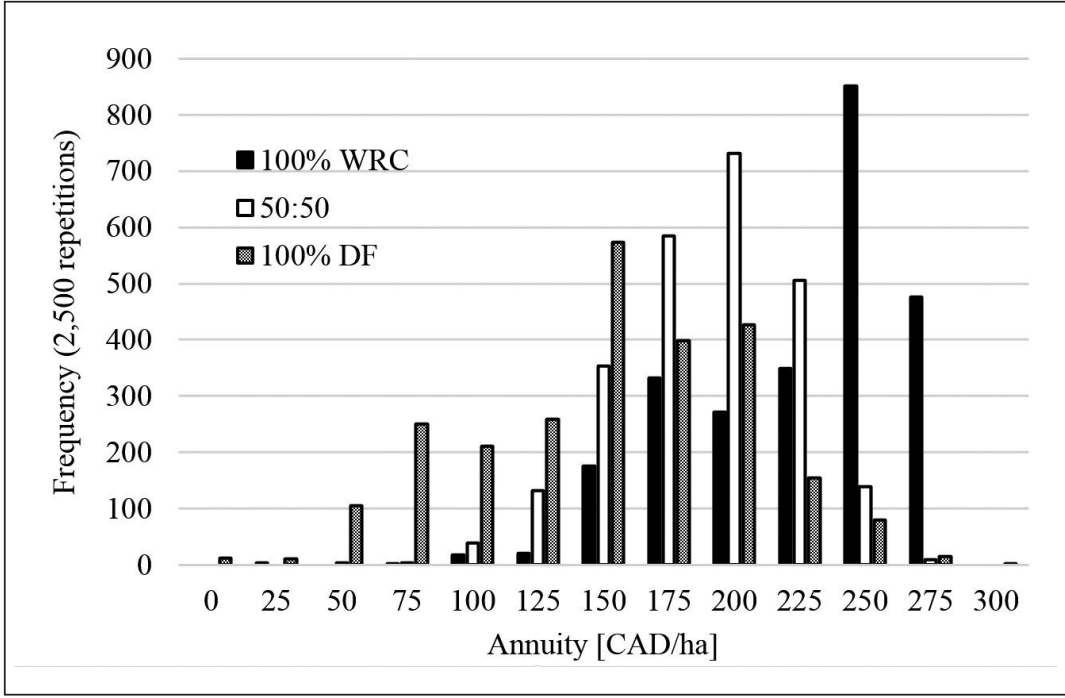

Fig. 3. Exemplary distribution of 2500 calculated annuities for the two mono species stands as well as a 50:50 mixture between WRC and DF based on the "Cones" portfolio.

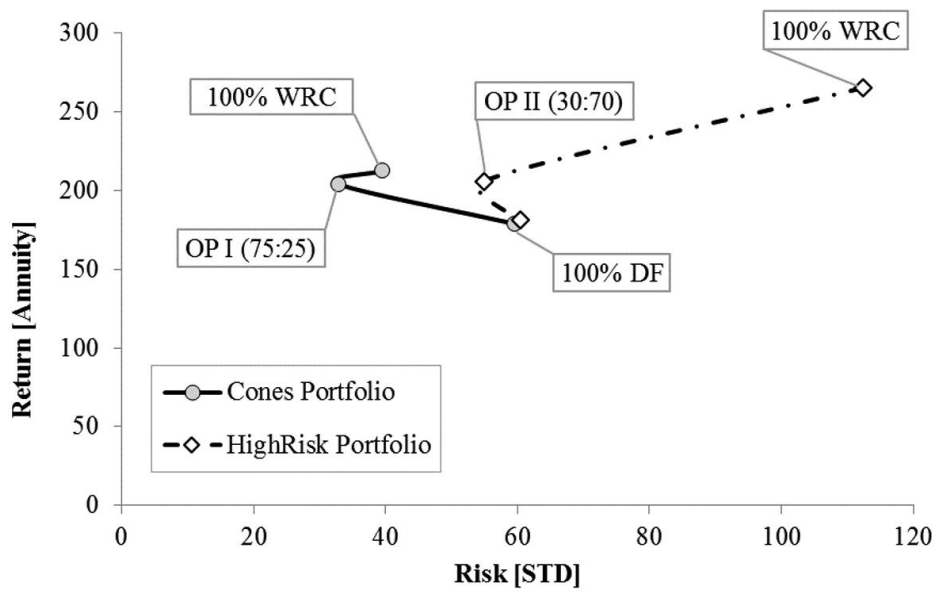

Fig. 4. Portfolios made up of western redcedar (WRC) and Douglas-fir (DF). The "Cones" scenarios optimum portfolio (OP I) is made up of 75\% WRC and 25\% DF, whilst the "High Risk" scenarios optimum portfolio (OP II) is made up of only $30 \%$ WRC and $70 \%$ DF.

cial consequences must be laid within an acceptable framework. Our results indicate benefits that arise from holding portfolios of WRC and DF when deer browsing is considered. Generally, working species mixtures can be a financially interesting solution. We argue that with a growing need to find management alternatives to attenuate climate change consequences, such as increasing damages by windthrow or insect calamities (Lemprière et al. 2008, Williamson et al. 2008), species mixtures will show even stronger benefits.

Identification of optimal management strategies for forests that fully consider and effectively integrate ecological processes (e.g., natural stand regeneration) and economic benefits are therefore-today more than ever-of highest relevance. WRC has particularly wide ecological amplitude accordingly it is an ideal species for combatting climate change challenges (Lesher and Henderson 2010).

The high relevance of mixed species stands is also reflected in the Forest Practices Code of BC: "Reasons for promoting a species mix include ..., improving stand resilience to damaging agents ..., increased future stand value, enhancing biodiversity, biological and ecological benefits ...." (B.C. Ministry of Forests 2000; page 11). And the unfortunate expression of low confidence in the skills of our forest practitioners and their commitment to sustainability in sentences like "Maximizing diversity on every site may result in stands that are difficult to manage. Therefore, planning for biological diversity is often best done at the landscape level." (B.C. Ministry of Forests 2000; page 12) can only be considered a challenge to prove-once more-that Canada's forest practitioners can and will remain amongst the global top players when it comes to sustainable forest management. Establishing land tenure systems that allow managers to benefit from investing in superior forests would be one definite step towards achieving this goal.

Last but not least, our research also proves the enormous potential of WRC seedlings that are less prone to browsing in the first place. Studies linking deer browsing and needle monoterpenes have led to the establishment of a breeding program for deer-resistant WRC for BC's coast (Russell 2008) that is already producing promising results. As planting pure stands of resistant WRC may force deer to change their foraging behaviour, further research should be carried out to determine an ideal mixture of susceptible and resistant WRC that will-in combination with other suitable species-reduce browsing risk in the long-term.

Concrete suggestions for reduction of browsing in WRC stands will-in combination with using portfolios to further offset financial risks-lead to economically highly desirable stands of a species that already has outstanding attributes regarding native heritage values, economics as well as ecology.

\section{Acknowledgement}

The authors would like to thank Yu Vivian Li of FPInnovations Vancouver for her help regarding an overview over logging and hauling costs using the software on FPInterface. Also, we would like to thank two anonymous reviewers for their valuable comments.

\section{References}

B.C. Ministry of Forests 2000. Establishment to free growing guidebook. Vancouver Forest Region. Rev. ed., Version 2.3. For. Prac. Br., B.C. Min. For., Victoria, B.C. Forest Practices Code of British 
Columbia Guidebook. Available from: http://www.for.gov.bc.ca/ tasb/legsregs/fpc/fpcguide/guidetoc.htm [accessed 28 July 2015]

B.C. Ministry of Forests, Mines and Lands 2010. The state of British Columbia's forests, $3^{\text {rd }}$ ed. Forest Practices and Investment Branch, Victoria, B.C. Available from: www.for.gov.bc.ca/hfp/sof/ index.htm\#2010_report [accessed 28 July 2015]

Brown, R. 1999. Planting Cedar-The Provincial Context and Legal Aspects-Planting a Mix of Species. In: Wiggins, G. (ed.): Proceedings of the cedar symposium: Growing western redcedar and yellowcypress on the Queen Charlotte Islands / Haida Gwaii, 133 p. Ministry of Forests, Victoria.

Carnol, M., L. Baeten, E. Branquart, J.C. Gregoire, A. Heughebaert, B. Muys, Q. Ponette and K. Verheyen. 2014. Ecosystem services of mixed species forest stands and monocultures: comparing practitioners' and scientists' perceptions with formal scientific knowledge. Forests. 87 (5): 639-653. doi: 10.1093/forestry/cpu024.

Clasen, C., V.C. Griess and T. Knoke. 2011. Financial consequences of losing admixed tree species: A new approach to value increased financial risks by ungulate browsing. Forest. Policy. Econ. 13 (6): 503-511. doi:10.1016/j.forpol.2011.05.005.

Gill, R. 1999. Deer Management to Protect Forest Vegetation - A British Perspective. In: Wiggins, G. (ed.): Proceedings of the cedar symposium: Growing western redcedar and yellow-cypress on the Queen Charlotte Islands / Haida Gwaii, 133 p. Ministry of Forests, Victoria.

Griess V.C. and T. Knoke. 2011. Growth Performance, Windthrow, Insects - Meta-Analyses of Economic Influence Factors for Mixed Species Stands in Boreal and Northern Temperate Biomes. Can. J. For. Res. 41 (6): 1141-1159. doi:10.1139/x11-042.302.

Griess, V.C., R. Acevedo, F. Härtl, K. Staupendahl and T. Knoke. 2012. Does mixing tree species enhance stand resistance against natural hazards? A case study for spruce. For. Ecol. Manage. 267: 284-296. doi:10.1016/j.foreco.2011.11.035.

Griess, V.C. and T. Knoke. 2013. Bioeconomic modelling of mixed Norway spruce - European beech stands: Economic consequences of considering ecological effects. Eur. J. For. Res. 132 (3): 511-522. doi:110.1007/s10342-013-0692-3.

Henigman, J. 1999. Seedling Protection from Deer Browsing. In: Wiggins, G. (ed.) Proceedings of the cedar symposium: Growing western redcedar and yellow-cypress on the Queen Charlotte Islands / Haida Gwaii, 133 p. Ministry of Forests, Victoria.

Knoke, T. and A.W. Hahn. 2007. Baumartenvielfalt und Produktionsrisiken: Ein Forschungseinblick und -ausblick. Schweiz. Z. Forstwes. 158 (10): 312-322. doi:10.3188/szf.2007.0312

Knoke, T. and J. Wurm. 2006. Mixed forests and a flexible harvest policy: A problem for conventional risk analysis? Eur. J. For. Res. 125 (3) 303-315

Lesher, R.D and J.A. Henderson. 2010. Ecology and distribution of western redcedar and Alaska yellowcedar in northwestern Washington. United States Department of Agriculture, Forest Service, Pacific Northwest Research Station. General Technical Report PNW-GTR828. Available from http://www.fs.fed.us/pnw/pubs/pnw_gtr828.pdf [accessed 31 July 2015]

Lempriere, T.C., P. Bernier, A. Carroll, M. Flannigan, R. Gilsenan and D. McKenney. 2008. The importance of forest sector adaptation to climate change. Rep. NOR-X-416. Edmonton. Available from: http://publications.gc.ca/pub?id=9.619001\&sl=0 [accessed 28 July 2015]

Le Page, P. and A. Banner. 2005. Seedling Browse Guard Trial on the North Coast of British Columbia. Forest Service BC Extension Note \#56. Available from https://www.for.gov.bc.ca/rni/Research/ Extension_notes/Extension_Notes.htm [accessed 28 July 2015]
Le Saout, S., S. Chollet, S. Chamaillé-Jammes, L. Blanc, S. Padié, T. Verchere, A.J. Gaston, M.P. Gillingham, O. Gimenez, K.L. Parker, D. Picot, H. Verheyden and J.L Martin. 2014. Understanding the paradox of deer persisting at high abundance in heavily browsed habitats. Wildlife Biol. 20: 122-135. doi: 10.2981/wlb.13048 Log Market Reports 2014. Timber Pricing Branch Publications. Available from www.for.gov.bc.ca/hva/logreports_coast.htm [accessed 28 July 2015]

Markowitz H. 1952. Portfolio Selection. The Journal of Finance 7: 77-91. doi:10.1111/j.1540-6261.1952.tb01525.x

Montigny, L. and G. Nigh. 2007. Growth and Survival of Douglasfir and Western Redcedar Planted at Different Densities and Species Mixtures. BC. Min. For. Range, Res. Br., Victoria, Technical Report \#44. Available from https://www.for.gov.bc.ca/hfd/pubs/Docs/Tr/ Tr044.htm [accessed 28 July 2015]

Neuner, S., B. Beinhofer and T. Knoke. 2013. The optimal tree species composition for a private forest enterprise - applying the theory of portfolio selection. Scand. J. Forest. Res. 28 (1): 38-48. doi: 10.1080/02827581.2012.683038.

Neuner S, A. Albrecht, D. Cullmann, F. Engels, V.C. Griess, A.W. Hahn, M. Hanewinkel, F. Härtl, C. Kölling, K. Staupendahl and T. Knoke. 2015. Survival of Norway spruce remains higher in mixed stands under a dryer and warmer climate. Glob. Change. Biol. 21 (2) 1365-2486. doi: 10.1111/gcb.12751

Panwar, R., E. Nybakk, J. Pinkse, and E. Hansen. 2015. Being good when not doing well: Examining the effect of the economic downturn on small manufacturing firms' ongoing sustainability-oriented initiatives. O \& E, doi: 10.1177/1086026615573842.

Pretzsch, H. and G. Schuetze. 2014. Size-structure dynamics of mixed versus pure forest stands. Forest. Sys. 23 (3): 560-572. doi: 10.5424/fs/2014233-06112.

Rößiger, J., V.C. Griess, F. Härtl, C. Clasen, and T. Knoke. 2013. How economic performance of a stand increases due to decreased failure risk associated with the admixing of species. Ecol. Model. 255: 58-69. doi: 10.1016/j.ecolmodel.2013.01.019.

Russell J. 2008. Deployment of deer -resistant western redcedar (Thuja plicata). In R.K. Dumroese and L.E. Riley. Proceedings of the Forest Nursery Association of British Columbia Western Forest and Conservation Nursery Association Combined Meeting, Sidney, BC 17-19 September 2007. pp. 149-153. United States Department of Agriculture, Forest Service, Rocky Mountain Research Station. Available from http://www.fs.fed.us/rm/pubs/rmrs_p057.html [accessed 28 July 2015]

Sharpe, W.F. 1994. The Sharpe Ratio. The Journal of Portfolio Management 21 (1): 49-58. doi:10.3905/jpm.1994.409501

TIPSY 4.3 (2013) Available from http://www.for.gov.bc.ca/hts/ growth/tipsy/tipsy_description.html [accessed 28 July 2015]

Vose, D. 2008. Risk Analysis, A Quantitative Guide ( $3^{\text {rd }} \mathrm{ed}$.). Wiley, Chichester.

Williamson, T., D. Price, J. Beverly, P. Bothwell, B. Frenkel, J. Park, and M.N. Patriquin. 2008. Assessing potential biophysical and socioeconomic impacts of climate change on forest-based communities: a methodological case study. Rep. NOR-X-415E., Edmonton. Available from https://cfs.nrcan.gc.ca/publications?id=29156 [accessed 28 July 2015] 